\title{
Association between serum interleukin (IL)-12 level and severity of non-alcoholic fatty liver disease (NAFLD)
}

\author{
DARMADI DARMADI ${ }^{1}$, RISKA HABRIEL RUSLIE ${ }^{2}$ \\ ${ }^{1}$ Department of Internal Medicine, Faculty of Medicine, Universitas Sumatera Utara, \\ Dr Mansyur 5, Medan, Indonesia \\ ${ }^{2}$ Department of Child Health, Faculty of Medicine, Universitas Prima Indonesia, \\ Ayahanda 68A, Medan, Indonesia
}

\begin{abstract}
What is new?
Serum IL-12 level is associated with NAFLD severity. Elevation in serum IL-12 level is in line with more severe NAFLD based on BARD score and NAFLD fibrosis score. Positive correlation is observed between serum IL-12 level and BARD score.

Introduction. Non-alcoholic fatty liver disease (NAFLD) is one of the most common liver diseases worldwide. Lipid accumulation in the liver triggers inflammation and leads to NAFLD. Prolonged inflammation will worsen the disease progression. Pro-inflammatory cytokines, including interleukin (IL)-12, plays a role in the inflammatory process. This study aimed to determine the association between IL-12 and NAFLD severity.

Methods. A cross-sectional study was conducted between January and July 2019 in Haji Adam Malik Hospital Medan, Indonesia. Subjects were patients aged 18 years or older diagnosed with NAFLD based on ultrasound. Exclusion criteria were excessive alcohol consumption, other primary liver diseases, malignancies, and cardio-metabolic disturbances. Serum IL-12 level was determined using an enzyme-linked immunosorbent assay method. The severity of NAFLD was assessed using the BARD score and NAFLD fibrosis score.

Results. A total of 100 subjects were enrolled with male predominant. The mean age of subjects was $54.97 \pm 8.85$ years, and the most frequent comorbidity was obesity. Most subjects had mild to moderate disease progression. Serum IL-12 level was higher in more severe NAFLD based on ultrasound grading $(\mathrm{P}<0.001)$, BARD score $(\mathrm{P}=0.003)$, and NAFLD fibrosis score $(\mathrm{P}=0.005)$. A positive correlation was observed between serum IL-12 level and BARD score $(\mathrm{P}<0.001)$ with sufficient accuracy (AUC $=0.691, \mathrm{P}=0.014$ ).

Conclusion. Serum IL-12 level was associated with the severity of NAFLD. Higher serum IL12 level was observed in more severe NAFLD progression.
\end{abstract}

Key words: BARD score, fibrosis, interleukin-12, non-alcoholic fatty liver disease.

\section{INTRODUCTION}

Liver disease has a high prevalence globally and may be caused by obesity, virus, alcohol, drugs, and toxins. Those agents trigger inflammation, create free radicals, and damage the liver [1,2]. Non-alcoholic fatty liver disease (NAFLD) is a liver disease caused by inflammation and marked by excessive ( $\geq 5 \%)$ lipid accumulation in liver tissue of subject who does not consume excessive alcohol. This condition may progress to steatohepatitis, fibrosis, cirrhosis, and hepatocellular carcinoma [1-5].

Cytokines are proteins that play an essential role in intercellular communication. The binding of cytokine with its receptor will trigger an alteration in cell function and phenotype. Interleukins (IL) are cytokines mediating the interaction between leukocytes or leukocyte and other cells. Interleukins may have pro- or anti-inflammatory effects. Interleukins play an essential role in chronic liver diseases. A previous study showed that IL-12 caused innate lymphoid cells to accumulate and activate in adipose tissue, thus secreting macrophage chemoattractant and causes inflammation [5]. IL-12 itself is a proinflammatory cytokine that aggravates liver damage, including NAFLD, by activating cytotoxic $T$ lymphocytes and promoting apoptosis of hepatocytes [6]. If the inflammation persists for an extended or if the host's inflammatory response is dysregulated, liver damage will be more severe, marked by accumulation fibrous tissues $[1,2,8,9]$.

Literature regarding the relationship between interleukins and staging of NAFLD is scarce. It is vital to predict the stage of NAFLD in order to administer proper management of the disease. We 
aimed to determine the association between serum IL-12 level and severity of NAFLD.

\section{MATERIALS AND METHODS}

\section{Study design and subjects}

This cross-sectional study was conducted in Haji Adam Malik Hospital Medan, Indonesia, between January and July 2019. A total of 100 subjects were enrolled in this study. The inclusion criteria were male or female aged 18 years or older who were diagnosed with NAFLD from two ultrasound examinations by two different radiologists. Subjects who had excessive alcohol consumption (more than $140 \mathrm{~g} /$ week for males and more than $70 \mathrm{~g} /$ week for females), viral or drug-induced or autoimmune liver diseases, malignant tumors, severe cardiopulmonary disorders, renal dysfunction, severe inflammatory diseases, thyroid dysfunction, and pregnancy were excluded from the study. This study was approved by the Institutional Review Board of Universitas Sumatera Utara with register number 419/TGL/KEPK FK USU-RSUP HAM/2018.

\section{Ultrasound and laboratory examinations}

Ultrasound parameters such as parenchymal brightness, liver-to-kidney contrast, deep beam attenuation, bright vessel walls, and gallbladder wall definition were applied in diagnosing NAFLD [10]. We used Toshiba Nemio 20 sonography machine with a $3.5-\mathrm{MHz}$ probe (Toshiba, Tokyo, Japan) in this study. Serum was obtained from each subject to determine IL-12 level by enzymelinked immunosorbent assay (ELISA). Human IL12 p70 Quantikine ELISA kit (R\&D Systems, Minneapolis, USA) was utilized in this study. The IL-12 levels were expressed in $\mathrm{pg} / \mathrm{mL}$ unit.

\section{NAFLD severity measurement}

Qualitative ultrasound grades of NAFLD were conveniently labeled mild, moderate, or severe or grade 0 to 3 (with 0 being normal). Grade 1 (mild) was represented by a slight diffuse increase in fine echoes in the hepatic parenchyma with normal visualization of the diaphragm and intrahepatic vessel borders. Grade 2 (moderate) was represented by a moderate diffuse increase in fine echoes with slightly impaired visualization of the intrahepatic vessels and diaphragm. Grade 3 (marked) was represented by a marked increase in fine echoes with poor or no visualization of the intrahepatic vessel borders, diaphragm, and posterior portion of the liver's right lobe [10]. Scoring systems for NAFLD severity using BARD (body mass index (BMI): aspartate aminotransferase/alanine aminotransferase (AST/ ALT), diabetes) score, and NAFLD fibrosis score. BARD score was determined by BMI $\left(<28 \mathrm{~kg} / \mathrm{m}^{2}\right.$ scored $0, \geq 28 \mathrm{~kg} / \mathrm{m}^{2}$ score 1$)$, AST/ALT ratio $(<0.8$ scored $0, \geq 0.8$ scored 2$)$ and diabetes type 2 (scored 1 if present). NAFLD fibrosis score was counted as $[-1.675+0.037 \mathrm{x}$ age (years) $+0.094 \times$ BMI $\left(\mathrm{kg} / \mathrm{m}^{2}\right)+1.13 \mathrm{x}$ impaired fasting glucose/ diabetes $($ yes $=1$, no $=0)+0.99 \times$ AST/ALT ratio $0.013 \times$ platelet $\left(\times 10^{9} / \mathrm{L}\right)-0.66 \times$ albumin $(\mathrm{g} / \mathrm{dL})$ ] were applied. [4] BARD scores were categorized into high $(\geq 2)$ and low $(<2)$ scores, while NAFLD fibrosis scores into F0-F2 $(<-1.455)$, indeterminate $(-1.455-0.675)$, and F3-F4 $(>0.675)$.

\section{Statistical analysis}

Kolmogorov-Smirnov test was used to determine the normality of numerical data. Normally distributed data were reported as mean \pm standard deviation. The difference in serum IL-12 levels between groups was evaluated using independent $t$-test and one-way ANOVA. Correlation between serum IL-12 level and BARD score was determined using the Pearson correlation test. Receiver Operating Curve and diagnostic accuracy were done to determine the accuracy of IL-12 to a high BARD score. Statistical analysis was conducted using Statistical Package for Social Sciences (SPSS) version 25.0 (IBM Inc., New York, USA). A P value of $<0.05$ was considered significant.

\section{RESULTS}

Subjects in this study had a mean age of $54.97 \pm 8.85$ years. Most of them (63\%) were males with obesity as the most common comorbidity $(60 \%)$. There were no significant differences between mild, moderate, and marked NAFLD in age $(\mathrm{P}=0.216)$, gender $(\mathrm{P}=0.117)$, and comorbidities (type 2 diabetes, dyslipidemia, and hypertension, $\mathrm{P}=0.481, \mathrm{P}=0.532$, and $\mathrm{P}=0.958$, respectively). There were significant differences in BMI $(\mathrm{P}<0.001)$ with significant differences found between mild and moderate $(\mathrm{P}=0.012)$ and mild and marked $(\mathrm{P}<0.001)$ in post-hoc analysis. There were no significant differences between moderate and marked NAFLD $(\mathrm{P}=0.223)$ (Table 1). 
Table 1

Demographic, clinical, and laboratory characteristics of subjects with NAFLD

\begin{tabular}{|c|c|c|c|c|}
\hline \multirow[b]{2}{*}{ Characteristics } & \multicolumn{3}{|c|}{ Degree of NAFLD } & \multirow[t]{2}{*}{$\mathbf{p}$} \\
\hline & $\begin{array}{c}\text { Mild } \\
(n=42)\end{array}$ & $\begin{array}{l}\text { Moderate } \\
(\mathbf{n}=\mathbf{3 3})\end{array}$ & $\begin{array}{l}\text { Marked } \\
(n=25)\end{array}$ & \\
\hline Age, year & $52.96 \pm 8.54$ & $55.35 \pm 9.1$ & $58.23 \pm 8.64$ & 0.216 \\
\hline $\begin{array}{l}\text { Gender, n (\%) } \\
\text { Male } \\
\text { Female }\end{array}$ & $\begin{array}{l}30(47.62 \%) \\
13(35.14 \%)\end{array}$ & $\begin{array}{l}21(33.33 \%) \\
13(35.14 \%)\end{array}$ & $\begin{array}{l}12(19.05 \%) \\
11(29.73 \%)\end{array}$ & 0.117 \\
\hline Comorbidities, n (\%) & & & & \\
\hline $\begin{array}{l}\text { Type } 2 \text { diabetes } \\
\text { Yes } \\
\text { No }\end{array}$ & $\begin{array}{l}22(42.31 \%) \\
20(41.67 \%)\end{array}$ & $\begin{array}{l}21(40.38 \%) \\
14(29.17 \%)\end{array}$ & $\begin{array}{c}9(17.31 \%) \\
14(29.17 \%)\end{array}$ & 0.481 \\
\hline $\begin{array}{l}\text { Dyslipidemia } \\
\text { Yes } \\
\text { No }\end{array}$ & $\begin{array}{c}10(30.3 \%) \\
31(46.27 \%)\end{array}$ & $\begin{array}{l}12(36.36 \%) \\
21(31.34 \%)\end{array}$ & $\begin{array}{l}11(33.33 \%) \\
15(22.39 \%)\end{array}$ & 0.532 \\
\hline $\begin{array}{l}\text { Hypertension } \\
\text { Yes } \\
\text { No } \\
\end{array}$ & $\begin{array}{c}5(38.46 \%) \\
37(42.53 \%) \\
\end{array}$ & $\begin{array}{c}5(38.46 \%) \\
28(32.18 \%) \\
\end{array}$ & $\begin{array}{c}3(23.08 \%) \\
22(25.29 \%)\end{array}$ & 0.958 \\
\hline Body mass index, $\mathrm{kg} / \mathrm{m}^{2}$ & $21.25 \pm 2.4$ & $23.56 \pm 2.02$ & $25.17 \pm 3.43$ & $<0.001$ \\
\hline AST, U/L & $24.68 \pm 5.65$ & $22.8 \pm 4.2$ & $22.73 \pm 4.93$ & 0.357 \\
\hline ALT, U/L & $32.28 \pm 6.54$ & $49.15 \pm 4.96$ & $72.93 \pm 5.47$ & $<0.001$ \\
\hline Platelet, $\times 10^{3} / \mathrm{mm}^{3}$ & $260.45 \pm 43.27$ & $274.2 \pm 50.36$ & $279.6 \pm 44.78$ & 0.256 \\
\hline Albumin, mg/dL & $4.1 \pm 0.6$ & $4.2 \pm 0.3$ & $4 \pm 0.2$ & 0.600 \\
\hline IL-12, pg/mL & $41.52 \pm 12.45$ & $49.6 \pm 17.5$ & $68.4 \pm 21.74$ & $<0.001$ \\
\hline
\end{tabular}

The mean serum IL-12 level in this study was 50.93 (SD 19.74) $\mathrm{pg} / \mathrm{mL}$. There were significant differences in ALT and IL-12 serum between degrees of NAFLD. Marked NAFLD had higher IL-12 serum and ALT serum compared to moderate $(\mathrm{P}=0.005$ and $\mathrm{P}=0.024$, respectively) and mild $(\mathrm{P}<0.001$ and $\mathrm{P}<0.001$, respectively) NAFLD. There were no significant differences between moderate and mild NAFLD in both IL-12 $(\mathrm{P}=0.345)$ and ALT $(\mathrm{P}=0.091)$.

The severity of NAFLD was also measured by BARD score and NAFLD fibrosis score. Serum IL-2 was compared between high and low BARD score, and there was significantly higher $(\mathrm{P}=0.003)$ IL-2 level in high BARD score $(\mathrm{n}=60 ; \mathrm{M}=55.87$, $\mathrm{SD}=21.67)$ compared to low BARD score $(\mathrm{n}=40$; $\mathrm{M}=42.41, \mathrm{SD}=12.12$ ). While based on NAFLD fibrosis score subjects with indeterminate score had significantly higher $(\mathrm{P}=0.005)$ serum $\mathrm{IL}-12$ level $(\mathrm{n}=47 ; \mathrm{M}=58.36, \mathrm{SD}=19.42)$ compared to subjects in F0-F2 score $(\mathrm{n}=53 ; \mathrm{M}=44.48, \mathrm{SD}=17.87)$.

The correlation between serum IL-12 level and BARD score was also determined. There was a significant moderate positive correlation between both parameters $(\mathrm{r}=0.494, \mathrm{P}<0.001)$. Predictive analysis showed sufficient accuracy of IL-12 to determine BARD score $(\mathrm{AUC}=0.691, \mathrm{P}=0.014)$ (Figure 1). Cut-off of IL-12 at more than $49.5 \mathrm{pg} / \mathrm{mL}$ could predict a high BARD score with an accuracy of $65 \%$ (Table 2 ).

\section{DISCUSSION}

NAFLD incidence is increasing due to a change in people's diet and lifestyle $[1,5,12]$. The global prevalence of NAFLD, according to the study, is $25.24 \%$, and it is increasing with age $[3,12,13]$. NAFLD is more common in males than females, but females are at higher risk of advanced fibrosis $[13,14]$. NAFLD is the most common liver disease in the USA, with an approximate incidence rate of $30 \%$. In China, its incidence rate is around $15 \%$. The incidence is predicted to be increased following the increase in metabolic syndrome incidence $[2,12]$. A meta-analysis reported the NAFLD mean age range of 30.7 to 76.2 years [12]. In this study, the mean age of subjects was 54.97 years. Males dominated the study's subjects.

Most patients have benign non-progressive disease courses, but particular portions develop cirrhosis and even hepatocellular carcinoma [8]. A previous study reported that $20 \%$ of patients with NAFLD would progress to cirrhosis, and $8 \%$ of them develop liver cancer [2]. However, this situation leads to an increased necessity for liver transplantation and its associated burden $[8,14]$. The mortality rate of patients with NAFLD was 0.77 per 1000 persons [14] and was strongly associated with hepatic steatosis [3]. Besides, NAFLD also increases the risk for extrahepatic complications such as cardiovascular disease and extrahepatic malignancies, particularly colorectal 
cancer [15]. Like some previous literature, subjects in this study mostly had mild to moderate NAFLD based on ultrasound grading. Based on the NAFLD fibrosis score, no subject was within the F3-F4 score group. In contrast, $60 \%$ of subjects were within a high score group based on the BARD score.

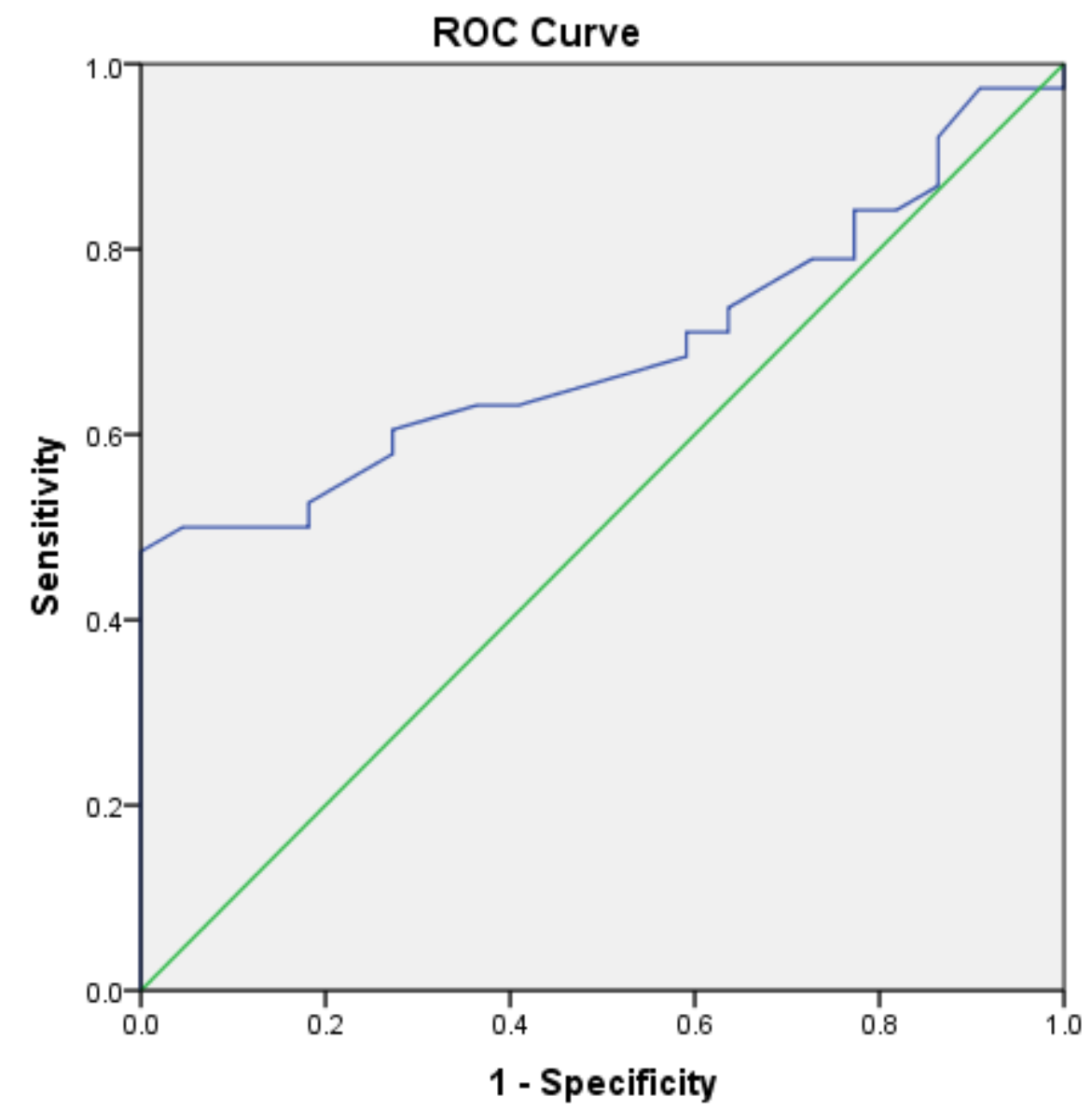

Diagonal segments are produced by ties.

Figure 1. Receiver Operating Curve (ROC) for IL-12 for BARD score in NAFLD patients.

Table 2

Diagnostic accuracy of IL-12 to predict high BARD score

\begin{tabular}{cccccccc}
\hline Cutoff & Sensitivity & Specificity & PPV & NPV & PLR & NLR & Accuracy \\
\hline$>49.5 \mathrm{pg} / \mathrm{mL}$ & $60.5 \%$ & $72.73 \%$ & $79.31 \%$ & $51.61 \%$ & 2.22 & 0.54 & $65 \%$ \\
\hline
\end{tabular}

The etiologies of NAFLD are obesity, insulin resistance, dyslipidemia, and diabetes $[1,4,5,12,13]$. Of all subjects with type 2 diabetes, $76 \%$ suffer from NAFLD. Furthermore, $90 \%$ of severely obese subjects have NAFLD [12]. NAFLD is initiated by the accumulation of lipids in the liver. Lipid accumulation increases the concentration of fatty acid and adipokines, which activate Kupffer cells [1, 2, 9, 16-18]. Activated Kupffer cells trigger the production of IL-12, which will activate natural killer cells in the liver $[2,8,17,19]$. Besides activating natural killer cells, IL-12 also increases the production of interferon- $\gamma$. In an experimental study, a diet containing high fat might increase Kupffer cell activation. Another study by Zhan et al. also reported that Kupffer cell depletion would reduce IL-12 expression [2]. Other cytokines produced from the inflammatory process in NAFLD's pathogenesis are tumor necrosis factor- $\alpha$, IL- 6 , IL- $1 \alpha$, IL- $1 \beta$, and IL-18 [16, 18]. In our study, the most common comorbidity accompanying NAFLD was obesity, followed by type 2 diabetes.

NAFLD diagnosis can be made based on a combination of elevated liver enzymes and the presence of hepatic steatosis from ultrasonography finding or liver biopsy $[4,13]$. Ultrasound becomes 
the most widely used diagnostic modality for NAFLD. Ultrasound is highly available, non-invasive, and affordable. The sensitivity and specificity of ultrasound in diagnosing NAFLD are $85 \%$ and $95 \%$, respectively [14]. The gold standard for diagnosing NAFLD and determining its severity is a liver biopsy. However, this procedure is too invasive and possesses a high false-negative rate $[14,20]$. In patients with advanced disease, low albumin, and elevated bilirubin level may be found [4]. Other supporting examinations for NAFLD are liver enzymes, even though almost $80 \%$ are within normal values [14]. After confirming the diagnosis of NAFLD, clinicians should determine the severity of the disease [4]. There are several scoring systems to determine NAFLD grading, such as BARD (body mass index, aspartate/alanine aminotransferase, and diabetes ratio) score, APRI (aspartate aminotransferase to platelet ratio index), NAFLD fibrosis score, et cetera $[4,13]$. The BARD score is simple to use at primary and secondary healthcare facilities. It has been validated with sensitivity and specificity of $89 \%$ and $44 \%$, respectively. Another report stated that the BARD score of $\geq 2$ has a sensitivity of $91 \%$ and specificity of $66 \%$ [13]. The NAFLD fibrosis score consists of 6 variables, including age, hyperglycemia, body mass index, platelet count, albumin, and aspartate to alanine aminotransferase ratio $[4,13,14]$. With a cut off of 0.676 , it has sensitivity and specificity of 0.90 and 0.97 , respectively [4]. We utilized two scoring systems to measure NAFLD severity in this study i.e., BARD and NAFLD fibrosis scores.

Our study showed that serum IL-12 level was significantly associated with NAFLD ultrasound grading. Additionally, serum IL-12 level was also associated with NAFLD severity, according to the BARD score and NAFLD fibrosis score. A moderate positive correlation was observed between serum IL-12 level and BARD score with sufficient accuracy in cut-off at more than $49.5 \mathrm{pg} / \mathrm{mL}$ to predict high BARD score. This study result is discordant to another study by Tarantino et al. [21], which IL-12 cannot predict hepatic steatosis, but the severity of hepatic steatosis in this study was determined by using ultrasound. As per our patient's characteristics has significant differences in IMT; we used the BARD score to determine if IL-12 could predict severity, as ultrasound can be biased in patients with abdominal fat thickness [22] and the BARD score had high sensitivity [23].

IL-12 hampers liver damage in chronic liver disease. IL-12 is a pro-inflammatory cytokine that plays a role in stimulating T-helper (Th)-1 cells and inhibition of Th-2. Overproduction of IL-12 leads to an over-reactive inflammatory process and organ injury, including the liver [7]. A study by Ajmera et al. showed that there were several biomarkers associated with NAFLD severity. A positive association was observed between IL-8, monocyte chemoattractant protein-1, resistin, soluble IL-1 receptor I, soluble IL-2 receptor $\alpha$, and TNF- $\alpha$. On the other hand, insulin-like growth factor II was negatively associated with NAFLD severity [20]. Other literature stated that increased pro-inflammatory cytokines, including IL-12, is observed in patients with NAFLD [17]. A study reported that IL-12 production is increased in mice with hepatosteatosis. Other pro-inflammatory cytokines such as TNF $\alpha$ and IFN $\gamma$ are also increased [19].

To our knowledge, this is the first study regarding the role of IL-12 in NAFLD in the Indonesian population. However, this study has several limitations. Liver biopsy as a gold standard diagnostic procedure for NAFLD was not done in our subjects, and there were only 100 subjects enrolled in this study. This study also did not control the chronic treatment the patient has received before enrollment. This study gives initial data that need further analysis to be extrapolated to a larger population.

\section{CONCLUSION}

Serum IL-12 level has a positive association with the severity of NAFLD. Serum IL-12 level may be considered as one of the supporting tools in determining NAFLD severity.

Introducere. Steatoza hepatică non-alcoolică (NAFLD) este o patologie frecventă în întreaga lume. Acumularea lipidelor intrahepatic determină inflamație și duce la NAFLD. Inflamația cronică se asociază cu progresia bolii. Citokinele proinflamatorii (inclusiv IL-12) contribuie la progresia bolii. Scopul studiului a fost de a determina asocierea dintre IL-12 și severitatea NAFLD.

Metode. A fost realizat un studiu transversal în perioada ianuarie-iulie 2019 in spitalul din Haji Adam Malik Hospital Medan, Indonezia. Pacienții au avut vârstă peste 18 ani și diagnosticul NAFLD pus pe bază ecografiei abdominale. Criteriile 
de excludere au fost consumul de alcool, prezența altor boli hepatice, malignitatea și prezența afectării cardiometabolice. Nivelul seric IL-12 a fost evaluat folosind tehnica ELISA. Severitatea NAFLD a fost evaluată prin scorul BARD și scorul de fibroză NAFLD.

Rezultate. 100 de pacienți au fost recrutați. Vârsta medie a fost de 54,97 \pm 8,85 ani, iar obezitatea a fost principala comorbiditate. Majoritatea pacientilor au avut progresie NAFLD medie spre moderată. Nivelurile IL-12 au fost mai mari la pacienții cu NAFLD sever bazat pe evaluarea ecografică ( $p<0,001)$, scorul BARD $(p=0,003)$ și scorul fibrozei NAFLD $(p=0,005)$. S-a observat o corelație pozitivă intre scorul BARD și nivelul IL-12 $(p<0,001)$ cu acuratețe suficientă $(A U C=0,691$, $p=0,014)$.

Concluzii. Nivelurile serice ale IL-12 s-au asociat cu severitatea NAFLD. Niveluri mai mari ale IL-12 s-au observat cu progresia NAFLD.

Correspondence to: Darmadi Darmadi, M.D, Department of Internal Medicine, Faculty of Medicine, Universitas Sumatera Utara, Dr Mansyur 5, Medan, Indonesia

Tel. +6282112125325

E-mail: ign.darmadi@yahoo.com

Acknowledgement: The authors would like to thank all subjects who had participated in this study.

Conflict of interest disclosure: The authors declare that there are no conflicts of interest.

\section{REFERENCES}

1. LI S., HONG M., TAN H., WANG N., FENG Y. Insights into the role and interdependence of oxidative stress in inflammation in liver diseases. Oxid Med Cell Longev. 2016; 2016:4234061.

2. ZHAN Y., AN W. Roles of liver innate immune cells in nonalcoholic fatty liver disease. World J Gastroenterol. 2010; 16(37):4652-4660.

3. LIU Y., ZHONG G., TAN H., HAO F., HU J. Nonalcoholic fatty liver disease and mortality from all causes, cardiovascular disease, and cancer: a meta analysis. Sci Rep. 2019; 9:11124.

4. KUMAR A., SINGH AK., PANDA PK., NISCHAL N., SONEJA M. Non-alcoholic fatty liver disease diagnosis, grading and staging; a simplified tool for clinicians. JAM. 2017; 6(1):15-22.

5. LUCI C., VIEIRA E., PERCHET T., GUAL P., GOLUB R. Natural killer cells and type 1 innate lymphoid cells are new actors in non-alcoholic fatty liver disease. Front Immunol. 2019; 10:1192.

6. HAMMERICH L, TACKE F. Interleukins in chronic liver disease: lessons learned from experimental mouse models. Clin Exp Gastroenterol. 2014;7:297-306.

7. HAMMERICH L., TACKE F. Interleukins in chronic liver disease: lessons learned from experimental mouse models. Clin Exp Gastroenterol. 2014; 7:297-306.

8. ARRESE M., CABRERA D., KALERGIS AM., FELDSTEIN AE. Innate immunity and inflammation in NAFLD/NASH. Dig Dis Sci. 2016; 61(5):1294-1303.

9. GILES DA., MORENO-FERNANDEZ ME., DIVANOVIC S. IL-17 axis driven inflammation in non-alcoholic fatty liver disease progression. Curr Drug Targets. 2015; 16(12):1315-1323.

10. DASARATHY S., DASARATHY S., KHIYAMI A., JOSEPH R., LOPEZ R., MCCULLOUGH AJ. Validity of real time ultrasound in the diagnosis of hepatic steatosis: a prospective study. J Hepatol. 2009; 51(6):1061-1067.

11. SHANNON A., ALKHOURI N., CARTER-KENT C., MONTI L., DEVITO R., LOPEZ R., et al. Ultrasonographic quantitative estimation of hepatic steatosis in children with NAFLD. J Pediatr Gastroenterol Nutr. 2011; 53(2):190-195.

12. YOUNOSSI ZM., KOENIG AB., ABDELATIF D., FAZEL Y., HENRY L., WYMER M. Global epidemiology of nonalcoholic fatty liver disease - meta-analytic assessment of prevalence, incidence, and outcomes. Hepatology. 2016; 64(1):73-84.

13. DYSON JK., ANSTEE QM., MCPHERSON S. Non-alcoholic fatty liver disease: a practical approach to diagnosis and staging. Frontline Gastroenterol. 2014; 5(3):211-218.

14. JENNISON E., PATEL J., SCORLETTI E., BYRNE CD. Diagnosis and management of non-alcoholic fatty liver disease. Postgrad Med J. 2019; 95(1124):314-322.

15. SANNA C., ROSSO C., MARIETTI M., BUGIANESI E. Non-alcoholic fatty liver disease and extra-hepatic cancers. Int J Mol Sci. 2016; 17(5):717.

16. STOJSAVLJEVIC S., PALCIC MG., JUKIC LV., DUVNJAK LS, DUVNJAK M. Adipokines and proinflammatory cytokines, the key mediators in the pathogenesis of nonalcoholic fatty liver disease. World J Gastroenterol. 2014; 20(48):18070-18091. 
17. SUTTI S., ALBANO E. Adaptive immunity: an emerging player in the progression of NAFLD. Nat Rev Gastroenterol Hepatol. $2020 ; 17(2): 81-92$.

18. BRAUNERSREUTHER V., VIVIANI GL., MACH F., MONTECUCCO F. Role of cytokines and chemokines in non-alcoholic fatty liver disease. World J Gastroenterol. 2012; 18(8):727-735.

19. KREMER M., THOMAS E., MILTON RJ., PERRY AW., VAN ROOIJEN N., WHEELER MD. Kupffer cell and interleukin-12 dependent loss of natural killer T cells in hepatosteatosis. Hepatology. 2010; 51(1):130-141.

20. AJMERA V., PERITO ER., BASS NM., TERRAULT NA., YATES KP., GILL R., et al. Novel plasma biomarkers associated with liver disease severity in adults with nonalcoholic fatty liver disease. Hepatology. 2017; 65(1):65-77.

21. TARANTINO G., CITRO V, CONFORTI P, BALSANO C, CAPONE D. Is there a link between basal metabolic rate, spleen volume and hepatic growth factor levels in patients with obesity-related NAFLD? JCM. 2019; 8:1510.

22. XIAO G., ZHU S., XIAO X., YAN L., YANG J., WU G. Comparison of laboratory tests, ultrasound, or magnetic resonance elastography to detect fibrosis in patients with nonalcoholic fatty liver disease: A meta-analysis. Hepatol. 2017; 66:1486-501.

23. CLEVELAND E., BANDY A., VANWAGNER LB. Diagnostic challenges of nonalcoholic fatty liver disease/nonalcoholic steatohepatitis. Clin Liver Dis (Hoboken). 2018/04/20 ed. 2018;11:98-104.

Received $22^{\text {nd }}$ August 2020 